\title{
Under pressure: listing status and disinvestment in Japan*
}

\author{
Joseph J. Frencha, University of Northern Colorado \\ Ryosuke Fujitani ${ }^{\text {b }}$, Hitotsubashi University \\ Yukihiro Yasuda ${ }^{\mathrm{c}}$, Hitotsubashi University
}

This version: April 5, 2019

\begin{abstract}
:
We provide the first large sample comparisons of disinvestment by listed and unlisted firms. This study focuses on Japanese firms from 2001-2017, as this was a period of economic stagnation and financial reforms encouraging companies to restructure. We show that stock market listing is positively related to disinvestment. Listed firms disinvest $1.9 \%$ more than similar unlisted firms. Disinvestment activities of listed companies are also more sensitive to investment opportunities. Additionally, firms that disinvest show improvements in ROA and increases in future investment. Finally, we find that foreign (financial institution) ownership is positively (negatively) related to disinvestment.
\end{abstract}

Keyword: disinvestment, listed status, short-termism

JEL classification G31; G32; G34;

\footnotetext{
* We are grateful for the insightful comments provided by participants at a Monfort College of Business research seminar. Ryosuke Fujitani greatly appreciates financial support from a Grant-in-Aid for JSPS Research Fellow (No. JP17J03278) provided by Japan's Ministry of Education, Science, Sports, and Culture. Yukihiro Yasuda greatly appreciates the financial support from Mizuho Securities and from a Grant-in-Aid for Scientific Research (C) (No. JP17K03798) provided by Japan's Ministry of Education, Science, Sports, and Culture. Joseph French acknowledges financial support from the Tointon Research Fund.

a Monfort College of Business, University of Northern Colorado, Campus Box 128, Greeley Colorado 80639, USA. joseph.french@unco.edu

b Graduate School of Commerce and Management, Hitotsubashi University, 2-1 Naka Kunitachi Tokyo 1868601, Japan. cd171002@g.hit-u.ac.jp

c Graduate School of Business Administration, Hitotsubashi University, 2-1 Naka Kunitachi Tokyo 186-8601, Japan y.yasuda@r.hit-u.ac.jp
} 


\section{Introduction}

"Pressure pushing down on me, pressing down on you, no man asked for ... under pressure..." -Queen and David Bowie

Since 1992 the Japanese economy has been characterized by stagnate growth and lack luster corporate performance. A series of regulatory reforms in the early 2000's was designed to encourage firms to restructure. Diversified firms began to exit businesses either out of financial necessity or due to a perceived need to be focused to compete (Schaede, 2008). In this letter, we consider the impacts of stock market listing on disinvestment behavior of Japanese firms.

The dark-side of stock market listing conjectures that listing on public markets induces short-term pressures, which leads to myopic behavior by managers. Asker et al. (2015) show that in the United States short-termism distorts investment behavior of public listed firms. They find that public firms invest less and are less responsive to investment opportunities when compared to unlisted firms. Alternatively, stock market listing may increase monitoring and exert pressure on management to make difficult decisions, such as disinvestment or asset sales. Recently, Ikeda et al. (2018) show that entrenched managers who are isolated from market pressure avoid making difficult decisions and prefer to 'enjoy the quite life'. Stock market listing may also provide additional sources of financing and lead to more efficient investing activities. Indeed, Bakke et al. (2012) argue and present evidence that the liquidity of public firms induces them to invest more than their private counterparts. ${ }^{1}$

Our study complements the current literature by considering the impact of listing status on the disinvestment activities of Japanese firms during a period of corporate restructuring. We find that listed firms engaged in more disinvestment and their disinvestment is more sensitive to investment opportunities. Specifically, listed company's disinvestment is strongly positively related to industry $\mathrm{Q}$ indicating that listed firms disinvest more in industries that are potentially overvalued. Given the complex and changing ownership structures of Japanese firms over our sample period, we consider how ownership by various block-

\footnotetext{
${ }^{1}$ Additional evidence on differences in investment behavior between private and public firms is provided by Acharya and $\mathrm{Xu}$ (2017) who show that public firms spend more on R\&D and other finance dependent industries that their private counterparts. Gao, Hsu, and $\mathrm{Li}$ (2018) show that public firms tend to have patents in less risky industries.
} 
holders impact disinvestment ${ }^{2}$. We show that higher levels of ownership by foreign investors (financial institutions and directors) encourages (discourages) dis-investment. Our findings indicate that listing and foreign investor monitoring exerts pressure on management to divest and sell assets.

In the next phase of our analysis, we consider if such disinvestment beneficial. The theory on disinvestment is well established. In their seminal paper, Berger and Ofek (1995) show that diversification is sub-optimal and that individual business units are more valuable separated than together. The asset allocation hypothesis therefore suggests that asset sales should be related to improvements in firm performance (Maksimovic and Phillips, 2002, Yang, 2008). Alternatively, the financing hypothesis proposes that firms disinvest to lower financing costs (Lang et al., 1995, Bates, 2005). We find support for both hypotheses. Our results indicate that ROA increases in the years immediately following asset sales. Disinvestment and asset sales are also significantly related to future investment by Japanese firms.

The remainder of the paper proceeds as follows. Section 2 describes our sample and presents our empirical methods, Section 3 discusses the empirical results, and Section 4 concludes.

\section{Research design}

\subsection{Sample: Japanese listed and unlisted public firms}

Japanese firms are selected as our sample for two reasons: 1) The shear amount of asset sales and disinvestment by Japanese firms, and 2) Financial and ownership data availability for unlisted firms. The Japanese Financial Instruments and Exchange Act (J-FIEA) mandates that audited financial statements be filed for any firm with over 1,000 shareholders. ${ }^{3}$ This act applies to both listed and unlisted firms, which is a key different from the reporting requirements in many countries. ${ }^{4}$ Our data set also contains ownership structures of both listed and unlisted firms. Prior research shows possible confounding effects of being listed and agency costs caused by separation of ownership. Most studies are unable to control

\footnotetext{
2 The ownership structure of Japanese corporations has dramatically changed in the decade following the financial reforms of the 2000's known as the 'Accounting Big Bang'. One important change is that bank ownership of corporations has declined, and foreign ownership has increased.

3 This is the Japanese analog of the U.S. Securities and Exchange Administration's 10-K filings. Previous research uses similar unlisted firms in US based studies. See: Gao and Li (2015), Gao, Harford, and Li (2013; 2017; 2018), Acharya and Xu (2017) and Badertscher et al. (2017). Allee and Badertscher (2019) use unlisted firms that are required to report $10-\mathrm{K}$. However, note that they consider these unlisted firms as private ones to compare with public firms.

${ }^{4}$ French, Fujitani, and Yasuda (2018) describe in detail the institutional background of disclosure requirements.
} 
for the ownership structure of unlisted firms due data constraints.

We investigate the disinvestment behavior of these listed and unlisted companies from March 2000 through April 2017. Our sample consists of 2,584 unlisted and 44,595 listed firms for a total 47,179 firm-year observations. All the data are obtained from Nikkei NEEDS Financial Quest 2.0 (FQ). Following existing literature, we exclude financial firms and winsorize each variable falling in the top or bottom $1 \%$.

\subsection{Models}

We perform Heckman's (1979) treatment effect model to address the endogeneity problem driven by the choice to be listed. In the first stage model, we estimate the probability to be listed by probit model as follows:

$$
\begin{aligned}
\text { listed }_{i, t}=\alpha_{0} & +\alpha_{1} \text { ln_sales }_{i, t-1}+\alpha_{2} \text { adj_sales_growth } \\
& +\alpha_{3} \text { adj_t } \text { roa }_{i, t-1}+\alpha_{4} \text { leverage } e_{i, t-1}+\alpha_{5} \text { inv }_{i, t-1}+\varepsilon_{i, t}
\end{aligned}
$$

where the subscripts $i$ and $t$ index firm and year, respectively. The dependent variable listed, defined by a dummy variable that takes one if a firm is listed in and zero is the firm is unlisted. Following Acharya and Xu (2017), we include the natural logarithm of sales (ln.sales), sales growth (sales_growth), return on assets (roa), leverage (leverage), and investment in tangible and intangible assets (inv). We limit the sample to parent firms when estimating inverse Mill's ratio for divestiture analysis, since firms with no subsidiaries cannot divest.

From the estimators in equation (1), we calculate inverse Mill's ratio (mills). Then estimate the second stage model by OLS estimation:

$$
\text { dis_invest }_{i, t}=\beta_{1} \text { listed }_{i, t-1}+\boldsymbol{\theta} \boldsymbol{z}+\vartheta \text { mills }_{\boldsymbol{f}}+\boldsymbol{f} \boldsymbol{e}+\varepsilon_{i, t}
$$

where the subscripts $i$ and $t$ index firm and year, respectively. The dependent variable takes one of two disinvestment proxies: 1) dis_invest is defined as the sum of all cash inflow from the sale of tangible and intangible assets, selling stocks of subsidiaries, affiliated firms and sales of short-term securities, 2) asset_sales is defined more narrowly as cash inflow from selling tangible and intangible assets divided by the sum of tangible and nontangible assets. We control for a variety of factors that have been found to impact disinvestment (vector $\boldsymbol{z}$ ). 
Industry Q (ind_q) and industry-adjusted sales growth (adj_sales_growth) are used to control for investment opportunities (inv_opportunites). ${ }^{5}$ We expect a negative relationship between disinvestment and inv_opportunities as firms in lower growth industries are likely to increase dis-investment. We include industry adjusted return on assets (adj_roa) to control for firm performance. Following Zhou, Li, and Svejnar (2011), current ratio (current_ratio) is included to control for short-term solvency. We expect the coefficient on current ratio is negative as dis-investment is more likely for liquidity constrained firms. We use firm age (ln_age) and size (ln_tast) as business cycle proxy. We control the number of subsidiaries (ln_subs) for considering the diversification of businesses at the firm level. Control variables also include four ownership variables: financial institutional ownership (sh_financial), foreign investor ownership (sh_foreign), and board member's ownership (sh_directors). Industry and year fixed effects are added in vector $f \boldsymbol{e}$. The definitions of all the variables are summarized in Table 1.

To understand the effect of listing status on the sensitivity of investment opportunities and to provide comparability to Asker et al (2015), we estimate the following model with interaction terms:

$$
\begin{aligned}
\text { dis_invest }_{i, t}= & \gamma_{1} \text { listed }_{i, t-1}+\gamma_{2} \text { listed }_{i, t-1} \times \text { inv_opportunities }_{i, t} \\
& +\gamma_{3} \text { listed }_{i, t-1} \times \text { adj_roa } a_{i, t-1}+\boldsymbol{\theta} \boldsymbol{z}+\vartheta \text { mills }_{\mathbf{f}}+\boldsymbol{f e}+\mathcal{E}_{i, t}
\end{aligned}
$$

\section{【Table 1】}

\section{Results}

\subsection{Main Results}

Table 2 contains summary statistics of firm's characteristics and differences between listed and unlisted firms. These univariate results demonstrate significant differences among large listed and unlisted firms. Listed firms engage in more disinvestment and asset sales (row 1, 2 and 3). Whereas, unlisted have more growth opportunities but are less profitable (row 4 and 5). Listed firms are older, larger (row 7 and 8) and have more subsidiaries than unlisted firms (row 9). Regarding ownership structure, listed firms have closer ties to financial institutions and foreign investors. Additionally, listed firms have higher ownership levels

\footnotetext{
5 See Table 1 for a detailed explanation of "adjusted".
} 
by directors.

\section{【Table 2】}

Table 3 contains the results of the first and second stage models. Column 1 shows that sales growth, return on assets and investment are positively related to the likelihood of being listed, but the leverage is negatively related. ${ }^{6}$

\section{【Table 3】}

Columns 2 and 3 present the main results of equation (1) when using dis_invest as the dependent variable. Columns 4 and 5 show the same results using the more narrowly defined asset_sales as the depend variable. The coefficient on listed is positive and statistically significant across all model constructs. Suggesting that listed firms disinvest more than unlisted firms. These results are fundamentally the same for both the broad measure of disinvestment (dis_invest) and the more narrowly defined disinvestment proxy (asset_sales). These results are both statistically and economically significant. For example, listed firms disinvest about 1.9\% percent more than comparable unlisted companies. Asker et al. (2015) show that short-term pressures cause public firms to invest less than comparable private firms. Our findings indicate that short-term pressures may also cause listed firms to disinvest more than unlisted ones.

Coefficients on ind_q and adj_sales_growth are negative and statistically significant as expected. adj_roa is negatively related to dis-invest, suggesting that relatively poorly performing firms tend to increase disinvestment. Current ratio, firm age, and firm size are all negatively related to disinvestment. As expected, firms with more subsidiaries disinvest at higher rates. These results support the notion that financially distressed firms may finance with asset sales. Shareholding of financial institutions negatively relates to disinvestment, whereas foreign shareholding increases disinvestment. We suspect that firms with higher levels of financial institutional ownership are less financially constrained and therefore divesture is less necessary (Campello, Graham, and Harvey, 2010). On the other hand, we show a strong positive relationship between foreign ownership and disinvestment behavior. This

\footnotetext{
6 The results on sales growth and return assets are opposite to Acharya and $\mathrm{Xu}$ (2017). However, note that all the coefficients are consistent with their results when using matching samples. In addition, the second stage results remain qualitatively similar when adj_sales_growth and addj_roa are used instead of sales_growth and adj_roa in the first stage regression.
} 
finding may stem from foreign investors acting as external monitors of management and encouraging asset sales and disinvestment to reduce the diversification discount and increase firm value.

Table 4 presents the results of equation (3). Columns 1 and 3 show that the coefficient on listed is negative and significant. However, the impact of listed status should be evaluated including the interaction terms. The net effects with both listed and listed $\times$ ind_q remains positive. The strongly positive coefficient on listed $\times$ ind_q shows the disinvestment behavior of listed firms is more sensitive to industry $Q$ than unlisted firms. This result complements the work of Asker et al. (2015) who find that unlisted firms investment behavior tends to be more sensitive to industry Q. Our results indicate the opposite sensitivities for disinvestment behavior in Japan. An alternative interpretation of this result is that firms tend to disinvest in industries that have high industry Q's that are potentially overvalued and listed firms are more sensitive to potential overvaluation. We note that the sensitivity of disinvestment behavior of listed and unlisted companies to adjusted sales growth is not statistically different.

\section{【Table 4】}

\subsection{Additional tests}

We test the robustness of our main findings using the caliper-based matching procedure based on industry-size nearest matching. We use the natural logarithm of total sales (ln.tast) as the size proxy. After matching, we re-estimate the first stage model of equation (1) and then calculate the inverse Mill's ratio. Finally, we estimate equations (2) and (3) using the match sample (Table 5). There are no notable changes in the main results of the paper.

In the final phase of our analysis, using propensity score matching (PSM), we consider the impact of disinvestment and asset sales on ROA and investment three-years forward (Table 6). We find that asset sales are positively related to ROA one-year forward. Results for the relationship between disinvestment and future ROA are weaker but found to be positive and significant at 10\% two-years into the future. Disinvestment and asset sales are positively related with future investment activities at the one- and two-year time horizons. These results indicate that disinvestment and asset sales are a positive activity which improve firm performance and asset allocation. 


\section{【Table 5】}

\section{【Table 6】}

\section{Closing thoughts}

Comprehensive data on unlisted firms are only recently becoming available. Most research on the differences between listed and unlisted firms have focused on positive capital investments in the United States. We supplement this literature using Japanese firms as our laboratory during a period of slow economic growth and regulatory changes promoting corporate restructuring. In the context of these economic realities, we study the impact of listing status on disinvestment.

Our analysis shows that listed firms disinvest more, and their disinvestment is more sensitive to investment opportunities. We also examine how ownership structure impacts disinvestment. Ownership structure of unlisted firms is rarely available and confounds analysis among listed and unlisted firms. Given our data, we show that foreign ownership (financial institutions) is positively (negatively) related with asset sales and dis-investment. Our findings suggest that stock market listing and foreign ownership exert pressure on management and encourages disinvestment which reduces the widely known diversification discount. Finally, we consider if disinvestment produces better outcomes using PSM. We find that ROA improves in the years following asset sales. Additionally, we find convincing evidence that investment increases up to two-years following disinvestment or asset sales. Taken together our findings show that managers under pressure from market monitoring are more likely to make the difficult decision to disinvest. 


\section{References}

Acharya, Viral, and Zhaoxia Xu, 2017, Financial dependence and innovation: The case of public versus private firms, Journal of Financial Economics 124, 223-243.

Allee, Kristian D, and Brad A. Badertscher, 2019, Private versus Public Corporate Ownership: Implications for Future Profitability., Working Paper.

Asker, John, Joan Farre-Mensa, and Alexander Ljungqvist, 2015, Corporate investment and stock market listing: A puzzle?, Review of Financial Studies 28, 342-390.

Badertscher, Brad, Sharon Katz, Sonja Rego, and Ryan Wilson, 2017, Conforming Tax Avoidance and Capital Market Pressure, Working Paper.

Bakke, Tor-Erik, Candace E. Jens, and Toni M. Whited, 2012, The real effects of delisting: Evidence from a regression discontinuity design, Finance Research Letters, 9(4),183-193.

Bates, Thomas W, 2005, Asset Sales, Investment Opportunities, and the Use of Proceeds, Journal of Finance 60, 105-135.

Berger, Philip G., and Eli Ofek, 1995, Diversification's effect on firm value, Journal of Financial Economics 37, 39-65.

Campello, Murillo, John R. Graham, and Campbell R. Harvey, 2010, The real effects of financial constraints: Evidence from a financial crisis, Journal of Financial Economics 97, 470-487.

French, Joseph J., Ryosuke Fujitani, and Yukihiro Yasuda, 2018, Stock market listing, investment, and business groups: How firm structure impacts investment., Working paper.

Gao, Huasheng, Jarrad Harford, and Kai Li, 2013, Determinants of corporate cash policy: Insights from private firms, Journal of Financial Economics 109, 623-639.

Gao, Huasheng, Jarrad Harford, and Kai Li, 2017, CEO Turnover-Performance Sensitivity in Private Firms, Journal of Financial and Quantitative Analysis 52, 583-611.

Gao, Huasheng, Po-hsuan Hsu, and Kai Li, 2018, Innovation Strategy of Private Firms, Journal of Financial and Quantitative Analysis 53, 1-32.

Gao, Huasheng, and Kai Li, 2015, A comparison of CEO pay-performance sensitivity in privately-held and public firms, Journal of Corporate Finance 35, 370-388.

Heckman, James J., 1979, Sample Selection Bias as a Specification Error, Econometrica 47, 153.

Ikeda, Naoshi, Kotaro Inoue and Watanabe, 2018. "Enjoying the quiet life: Corporate decision-making by entrenched managers," Journal of the Japanese and International Economies, Elsevier, vol. 47(C), pages 55-69.

Lang, Larry, Annette Poulsen, and René Stulz, 1995, Asset sales, firm performance, and the agency costs of managerial discretion, Journal of Financial Economics 37, 3-37. 
Schaede, Ulrike, 2008, Choose and Focus: Japanese Business Strategies for the 21st Century (Cornell University Press).

Maksimovic, V. and Phillips, G. (2002), Do Conglomerate Firms Allocate Resources Inefficiently Across Industries? Theory and Evidence. The Journal of Finance, 57: 721-767.

Yang, L I U, 2008, The Real Determinants of Asset Sales, Journal of Finance 63, 2231-2262.

Zhou, Yue Maggie, Xiaoyang Li, and Jan Svejnar, 2011, Subsidiary divestiture and acquisition in a financial crisis: Operational focus, financial constraints, and ownership, Journal of Corporate Finance 17, 272-287. 
Table 1

Variable definitions

This table summarizes the definitions of all the variables used in this paper. All the variables are winsorized at top and bottom $1 \%$.

\section{Variables}

\section{dis_invest}

asset_sales

listed

adj_sales_growth

ind_q

adj_roa

ln_age

ln_asset

leverage

current_ratio

ln subs

sh_financial

$s h \_$foreign

sh_directors

\section{Definition}

The sum of cash inflow from purchase of tangible and intangible assets and of stocks of subsidiary or affiliated firms scaled by the sum of tangible, intangible assets, and investment security of subsidiary and affiliated firms.

Cash inflow from purchase of tangible and intangible assets scaled by sum of tangible and intangible assets scaled by the sum of tangible, intangible assets, and investment security of subsidiary and affiliated firms.

Indicator variable that takes 1 if a firm is listed in the stock market, 0 otherwise

Difference from industry average of return on assets, which is defined as the change in sales from the previous fiscal year divided by sales in the previous period

The weighted average of Tobin's q based on total assets for each industry

Difference from industry average of return on assets, which is defined as the operating income divided by the sum of tangible and tangible assets.

Natural logarithm of firm's age plus 1

Natural logarithm of total assets

Sum of short- and long-term debt scaled by total assets

Current assets divided by current liability

Natural logarithm of the number of subsidiaries plus one

Common stock ownership of financial intermediaries scaled by shares outstanding.

Common stock ownership of foreign investors scaled by shares outstanding.

Common stock ownership of board members scaled by shares outstanding. 
Table 2

Descriptive statistics

This table presents the descriptive statistics.

\begin{tabular}{|c|c|c|c|c|c|c|c|c|c|c|}
\hline \multirow{4}{*}{$\begin{array}{l}\text { dis_invest } \\
\text { asset_sales }\end{array}$} & \multicolumn{3}{|c|}{ Listed firms } & \multicolumn{3}{|c|}{ Unlisted firms } & \multicolumn{4}{|c|}{ Difference (Listed-Unlisted) } \\
\hline & \multirow{2}{*}{$\begin{array}{l}\text { Mean } \\
0.0501\end{array}$} & \multirow{2}{*}{$\begin{array}{l}\text { Median } \\
0.0111\end{array}$} & \multirow{2}{*}{$\begin{array}{l}\text { Std. } \\
0.1157\end{array}$} & \multirow{2}{*}{$\begin{array}{l}\text { Mean } \\
0.0299\end{array}$} & \multirow{2}{*}{$\begin{array}{r}\text { Median } \\
0.0033\end{array}$} & \multirow{2}{*}{$\begin{array}{l}\text { Std. } \\
0.0886\end{array}$} & \multicolumn{2}{|c|}{ Mean } & \multicolumn{2}{|c|}{ Median } \\
\hline & & & & & & & 0.0202 & $* * *$ & 0.0078 & $* * *$ \\
\hline & 0.0187 & 0.0019 & 0.0514 & 0.0148 & 0.0006 & 0.0491 & 0.0038 & $* * *$ & 0.0013 & $* * *$ \\
\hline adj_sales_growth & -0.0352 & -0.0389 & 0.1388 & 0.0008 & -0.0100 & 0.1501 & -0.0360 & $* * *$ & -0.0289 & $* * *$ \\
\hline ind_q & 1.1607 & 1.1266 & 0.2533 & 1.2309 & 1.2045 & 0.2552 & -0.0702 & $* * *$ & -0.0779 & $* * *$ \\
\hline adj_roa & 0.0015 & -0.0050 & 0.0659 & -0.0273 & -0.0270 & 0.0587 & 0.0289 & $* * *$ & 0.0221 & $* * *$ \\
\hline current_ratio & 2.0427 & 1.5439 & 1.6911 & 2.0954 & 1.0981 & 2.6385 & -0.0528 & & 0.4458 & $* * *$ \\
\hline ln_age & 3.7939 & 3.9703 & 0.5953 & 3.9753 & 4.0943 & 0.5385 & -0.1815 & $* * *$ & -0.1241 & $* * *$ \\
\hline ln_asset & 10.3566 & 10.2317 & 1.5099 & 9.5985 & 9.7392 & 1.6808 & 0.7582 & $* * *$ & 0.4924 & $* * *$ \\
\hline ln_subs & 1.7856 & 1.7918 & 1.2102 & 1.3150 & 1.3863 & 1.2204 & 0.4706 & $* * *$ & 0.4055 & $* * *$ \\
\hline sh_financial & 0.1767 & 0.1519 & 0.1295 & 0.0677 & 0.0400 & 0.0849 & 0.1091 & $* * *$ & 0.1119 & $* * *$ \\
\hline sh_foreign & 0.0733 & 0.0284 & 0.1001 & 0.0100 & 0 & 0.0572 & 0.0633 & $* * *$ & 0.0284 & $* * *$ \\
\hline sh_directors & 0.0897 & 0.0228 & 0.1327 & 0.0570 & 0.0085 & 0.1073 & 0.0327 & $* * *$ & 0.0143 & $* * *$ \\
\hline
\end{tabular}




\section{Table 3}

\section{Negative investment and listing status}

This table reports the results of models (1) and (2). The first column shows the results of the first stage model where we regress the listing indicator variable on the determinants of listing status by using probit model.

Columns (2)-(5) present the results of the second stage model. The results using negative investment (dis_invest) and asset sales (asset_sales) are presented in Columns (2)-(3) and (4)-(5), respectively. We measure investment opportunity as industry q (ind_q) or industry adjusted sales growth (adj.sg). Firm performance is defined by industry adjusted ROA (adj_roa). Other control variables include leverage (leverage), current ratio (current_ratio), natural logarithm of firm age (ln_age), natural logarithm of total assets ( $\left.l n \_a s s e t\right)$, natural logarithm of the number of subsidiaries (ln_subs), financial institution ownership (sh_financial), foreign shareholder ownership (sh_foreign), and board member ownership (sh_directors). We also control year and industry fixed effects. All the variables are winsorized at top and bottom 1\%. Standard errors are clustered at firm levels and are reported in parentheses. $* * *$, and $* * *$ indicate statistical significance at the $10 \%, 5 \%$, and $1 \%$ level, respectively.

\begin{tabular}{|c|c|c|c|c|c|c|}
\hline & \multirow{3}{*}{$\begin{array}{c}\text { First stage } \\
\text { listed } \\
(1) \\
\end{array}$} & & \multicolumn{4}{|c|}{ Second stage } \\
\hline & & & \multicolumn{2}{|c|}{ dis_invest } & \multicolumn{2}{|c|}{ asset_sales } \\
\hline & & & (2) & (3) & (4) & (5) \\
\hline \multirow{2}{*}{ In_sales } & $0.2254 * * *$ & listed & $0.0086 * * *$ & $0.0076 * * *$ & $0.0059 * * *$ & $0.0050 * * *$ \\
\hline & $(0.0234)$ & & $(0.0019)$ & $(0.0019)$ & $(0.0017)$ & $(0.0017)$ \\
\hline \multirow{2}{*}{ sales_growth } & $0.1191 *$ & ind_q & $-0.0154 * * *$ & & $-0.0143 * * *$ & \\
\hline & $(0.0637)$ & & $(0.0030)$ & & $(0.0027)$ & \\
\hline \multirow[t]{2}{*}{ roa } & $0.0852 * * *$ & adj_sales_growth & & $-0.0235 * * *$ & & $-0.0203 * * *$ \\
\hline & $(0.0283)$ & & & $(0.0036)$ & & $(0.0029)$ \\
\hline \multirow[t]{2}{*}{ leverage } & $-0.9930 * * *$ & adj_roa & $-0.1035 * * *$ & $-0.1083 * * *$ & $-0.0841 * * *$ & $-0.0882 * * *$ \\
\hline & $(0.1471)$ & & $(0.0089)$ & $(0.0091)$ & $(0.0075)$ & $(0.0076)$ \\
\hline \multirow[t]{2}{*}{ lagged_inv } & $0.8423 * * *$ & Leverage & $0.0416 * * *$ & $0.0474 * * *$ & $0.0367 * * *$ & $0.0418 * * *$ \\
\hline & $(0.1288)$ & & $(0.0040)$ & $(0.0041)$ & $(0.0035)$ & $(0.0036)$ \\
\hline \multirow[t]{3}{*}{ Constant } & $-0.5372 * *$ & current_ratio & -0.0004 & -0.0003 & $-0.0005^{* *}$ & -0.0004 \\
\hline & $(0.2210)$ & & $(0.0003)$ & $(0.0003)$ & $(0.0002)$ & $(0.0002)$ \\
\hline & & ln_age & $-0.0060 * * *$ & $-0.0064 * * *$ & $-0.0027 * * *$ & $-0.0030 * * *$ \\
\hline Observations & 47,179 & & $(0.0010)$ & $(0.0010)$ & $(0.0009)$ & $(0.0009)$ \\
\hline \multirow[t]{16}{*}{ Pseudo $\mathrm{R}^{2}$} & 0.112 & ln_asset & $-0.0075 * * *$ & $-0.0084 * * *$ & $-0.0056 * * *$ & $-0.0064 * * *$ \\
\hline & & & $(0.0007)$ & $(0.0007)$ & $(0.0006)$ & $(0.0006)$ \\
\hline & & ln_subs & $0.0048 * * *$ & $0.0048 * * *$ & $0.0021 * * *$ & $0.0021 * * *$ \\
\hline & & & $(0.0006)$ & $(0.0006)$ & $(0.0005)$ & $(0.0005)$ \\
\hline & & sh_financial & $-0.0237 * * *$ & $-0.0234 * * *$ & $-0.0174 * * *$ & $-0.0171 * * *$ \\
\hline & & & $(0.0041)$ & $(0.0041)$ & $(0.0037)$ & $(0.0037)$ \\
\hline & & sh_foreign & $0.0446 * * *$ & $0.0479 * * *$ & $0.0359 * * *$ & $0.0387 * * *$ \\
\hline & & & $(0.0062)$ & $(0.0062)$ & $(0.0054)$ & $(0.0054)$ \\
\hline & & sh_directors & $-0.0116 * * *$ & $-0.0107 * *$ & $-0.0081 * *$ & $-0.0073 * *$ \\
\hline & & & $(0.0042)$ & $(0.0042)$ & $(0.0036)$ & $(0.0035)$ \\
\hline & & mills_ratio & $-0.0632 * * *$ & $-0.0878 * * *$ & $-0.0589 * * *$ & $-0.0802 * * *$ \\
\hline & & & (0.0119) & $(0.0128)$ & $(0.0103)$ & $(0.0111)$ \\
\hline & & Year fixed effects & yes & yes & yes & yes \\
\hline & & Industry fixed effects & yes & yes & yes & yes \\
\hline & & Observations & 46,945 & 46,945 & 46,945 & 46,945 \\
\hline & & Adj. $\mathrm{R}^{2}$ & 0.0845 & 0.0431 & 0.0850 & 0.0437 \\
\hline
\end{tabular}




\section{Table 4}

\section{Interaction model}

This table reports the results of equation (3). The results using dis-investment (dis_invest) and asset sales (asset_sales) are presented in Columns (1)-(2) and (3)-(4), respectively. We measure investment opportunity as industry q (ind_q) or industry adjusted sales growth (adj_sales_growth). Firm performance is defined by industry adjusted ROA (ad_roa). The variables in interest are the interaction terms of listing indicator with investment opportunity and firm performance. Other control variables include leverage (leverage), current ratio (current_ratio), natural logarithm of firm age (ln.age), natural logarithm of total assets (ln_asset), natural logarithm of the number of subsidiaries ( $l n \_s u b s$ ), financial institution ownership (sh_financial), foreign shareholder ownership (sh_foreign), and board member ownership (sh_directors). We also control year and industry fixed effects. All the variables are winsorized at top and bottom 1\%. Standard errors are clustered at firm levels and are reported in parentheses. *, **, and $* * *$ indicate statistical significance at the $10 \%, 5 \%$, and $1 \%$ levels, respectively.

\begin{tabular}{|c|c|c|c|c|}
\hline & \multicolumn{2}{|c|}{ dis_invest } & \multicolumn{2}{|c|}{ asset_sales } \\
\hline & (1) & (2) & (3) & (4) \\
\hline \multirow[t]{2}{*}{ Listed } & $-0.0142 * *$ & $0.0065 * * *$ & $-0.0114^{*}$ & $0.0045 * * *$ \\
\hline & $(0.0070)$ & $(0.0018)$ & $(0.0064)$ & $(0.0016)$ \\
\hline \multirow[t]{2}{*}{ listed $\times$ ind_q } & $0.0174 * * *$ & & $0.0133 * * *$ & \\
\hline & $(0.0056)$ & & $(0.0051)$ & \\
\hline \multirow[t]{2}{*}{ listed $\times$ adj_sales_growth } & & 0.0178 & & 0.0167 \\
\hline & & $(0.0157)$ & & $(0.0142)$ \\
\hline \multirow[t]{2}{*}{ listed $\times$ adj_roa } & $-0.0711 *$ & $-0.0682 *$ & -0.0480 & -0.0441 \\
\hline & $(0.0368)$ & $(0.0360)$ & $(0.0317)$ & $(0.0310)$ \\
\hline \multirow[t]{2}{*}{ ind.q } & $-0.0315 * * *$ & & $-0.0266 * * *$ & \\
\hline & $(0.0058)$ & & $(0.0053)$ & \\
\hline \multirow[t]{2}{*}{ adj_sales_growth } & & $-0.0401 * *$ & & $-0.0360 * *$ \\
\hline & & $(0.0157)$ & & $(0.0142)$ \\
\hline \multirow[t]{2}{*}{ adj_roa } & -0.0342 & -0.0426 & -0.0373 & -0.0458 \\
\hline & $(0.0371)$ & $(0.0366)$ & $(0.0321)$ & $(0.0316)$ \\
\hline \multirow[t]{2}{*}{ Leverage } & $0.0401 * * *$ & $0.0467 * * *$ & $0.0357 * * *$ & $0.0414 * * *$ \\
\hline & $(0.0041)$ & $(0.0043)$ & $(0.0036)$ & $(0.0038)$ \\
\hline \multirow[t]{2}{*}{ current_ratio } & -0.0004 & -0.0003 & $-0.0005 * *$ & $-0.0004^{*}$ \\
\hline & $(0.0003)$ & $(0.0003)$ & $(0.0002)$ & $(0.0002)$ \\
\hline \multirow[t]{2}{*}{ ln_age } & $-0.0061 * * *$ & $-0.0065 * * *$ & $-0.0028 * * *$ & $-0.0031 * * *$ \\
\hline & $(0.0010)$ & $(0.0010)$ & (0.0009) & (0.0009) \\
\hline \multirow[t]{2}{*}{ ln_asset } & $-0.0074 * * *$ & $-0.0083 * * *$ & $-0.0055 * * *$ & $-0.0064 * * *$ \\
\hline & $(0.0007)$ & $(0.0007)$ & (0.0006) & $(0.0006)$ \\
\hline \multirow[t]{2}{*}{ ln_subs } & $0.0048 * * *$ & $0.0048 * * *$ & $0.0021 * * *$ & $0.0021 * * *$ \\
\hline & $(0.0006)$ & $(0.0006)$ & $(0.0005)$ & $(0.0005)$ \\
\hline \multirow[t]{2}{*}{ sh_financial } & $-0.0229 * * *$ & $-0.0231 * * *$ & $-0.0168 * * *$ & $-0.0169 * * *$ \\
\hline & $(0.0041)$ & $(0.0041)$ & $(0.0037)$ & $(0.0037)$ \\
\hline \multirow[t]{2}{*}{ sh_foreign } & $0.0446 * * *$ & $0.0481 * * *$ & $0.0359 * * *$ & $0.0389 * * *$ \\
\hline & $(0.0062)$ & $(0.0062)$ & $(0.0054)$ & $(0.0054)$ \\
\hline \multirow[t]{2}{*}{ sh_directors } & $-0.0121 * * *$ & $-0.0109 * * *$ & $-0.0084 * *$ & $-0.0074 * *$ \\
\hline & $(0.0042)$ & $(0.0042)$ & $(0.0036)$ & $(0.0036)$ \\
\hline \multirow[t]{2}{*}{ mills_ratio } & $-0.0578 * * *$ & $-0.0855 * * *$ & $-0.0551 * * *$ & $-0.0790 * * *$ \\
\hline & $(0.0124)$ & $(0.0135)$ & $(0.0107)$ & $(0.0117)$ \\
\hline Year fixed effects & yes & yes & yes & yes \\
\hline Industry fixed effects & yes & yes & yes & yes \\
\hline Observations & 46,945 & 46,945 & 46,945 & 46,945 \\
\hline Adj. $R^{2}$ & 0.0599 & 0.0619 & 0.0504 & 0.0525 \\
\hline
\end{tabular}




\section{Table 5}

\section{Matching sample analysis using treatment effect model}

This table shows the results of the models (2) and (3) using matched sample with treatment effect model. To construct matched sample, we use one-to-one industry-size matching procedure. Calculating inverse mills ratio using matched sample, we estimate the second stage model.

Columns (1)-(4) present the results of Model (2) using matched sample, where we regress disinvestment variable (dis_invest or asset_sales) on listed indicator and control variables. We measure investment opportunity as industry q (ind_q) or industry adjusted sales growth (adj.sg). Firm performance is defined by industry adjusted ROA (ad_roa). Other control variables include leverage (leverage), current ratio (current ratio), natural logarithm of firm age (ln age), natural logarithm of total assets (ln_tast), natural logarithm of the number of subsidiaries (ln_subs), financial institution ownership (sh_financial), foreign shareholder ownership (sh_foreign), and board member ownership (sh_directors). We also control year and industry fixed effects.

Columns (5)-(8) present the results of Model (3) using matched sample. All the variables are winsorized at top and bottom 1\%. Standard errors are clustered at firm levels and are reported in parentheses. *,**, and *** indicate statistical significance at the $10 \%, 5 \%$, and $1 \%$ levels, respectively.

\begin{tabular}{|c|c|c|c|c|c|c|c|c|}
\hline & \multicolumn{4}{|c|}{ Model (2) } & \multicolumn{4}{|c|}{ Model (3) } \\
\hline & \multicolumn{2}{|c|}{ dis_invest } & \multicolumn{2}{|c|}{ asset_sales } & \multicolumn{2}{|c|}{ dis_invest } & \multicolumn{2}{|c|}{ asset_sales } \\
\hline & (1) & (2) & (3) & (4) & (5) & (6) & (7) & (8) \\
\hline listed & $\begin{array}{c}0.0136^{* * *} \\
(0.0028)\end{array}$ & $\begin{array}{c}0.0124 * * * \\
(0.0027)\end{array}$ & $\begin{array}{c}0.0103 * * * \\
(0.0025)\end{array}$ & $\begin{array}{c}0.0092 * * * \\
(0.0025)\end{array}$ & $\begin{array}{c}-0.0153 \\
(0.0106)\end{array}$ & $\begin{array}{c}0.0107 * * * \\
(0.0028)\end{array}$ & $\begin{array}{l}-0.0154 \\
(0.0094)\end{array}$ & $\begin{array}{c}0.0077 * * * \\
(0.0025)\end{array}$ \\
\hline lited $\times$ ind_q $q$ & & & & & $\begin{array}{l}0.0228^{* *} \\
(0.0090)\end{array}$ & & $\begin{array}{c}0.0202 * * \\
(0.0080)\end{array}$ & \\
\hline lited $\times$ adj_sales_growth & & & & & & $\begin{array}{c}0.0013 \\
(0.0257)\end{array}$ & & $\begin{array}{c}0.0004 \\
(0.0220)\end{array}$ \\
\hline lited $\times$ adj_roa & & & & & $\begin{array}{c}-0.0994 * \\
(0.0509)\end{array}$ & $\begin{array}{c}-0.0845^{*} \\
(0.0497)\end{array}$ & $\begin{array}{l}-0.0867^{*} \\
(0.0445)\end{array}$ & $\begin{array}{l}-0.0735^{*} \\
(0.0434)\end{array}$ \\
\hline ind_q & $\begin{array}{c}-0.0210^{* *} \\
(0.0104)\end{array}$ & & $\begin{array}{c}-0.0200^{* *} \\
(0.0095)\end{array}$ & & $\begin{array}{c}-0.0304 * * * \\
(0.0110)\end{array}$ & & $\begin{array}{c}-0.0283^{* * *} \\
(0.0100)\end{array}$ & \\
\hline adj_sales_growth & & $\begin{array}{c}-0.0761 * * * \\
(0.0185)\end{array}$ & & $\begin{array}{c}-0.0671 * * * \\
(0.0159)\end{array}$ & & $\begin{array}{c}-0.0747 * * * \\
(0.0228)\end{array}$ & & $\begin{array}{c}-0.0655^{* * * *} \\
(0.0200)\end{array}$ \\
\hline adj_roa & $\begin{array}{c}-0.1183 * * * \\
(0.0352)\end{array}$ & $\begin{array}{c}-0.1927 * * * \\
(0.0406)\end{array}$ & $\begin{array}{c}-0.1054 * * * \\
(0.0309)\end{array}$ & $\begin{array}{c}-0.1710^{* * *} \\
(0.0355)\end{array}$ & $\begin{array}{c}-0.0591 \\
(0.0477)\end{array}$ & $\begin{array}{c}-0.1394 * * \\
(0.0547)\end{array}$ & $\begin{array}{l}-0.0538 \\
(0.0423)\end{array}$ & $\begin{array}{c}-0.1245^{* * *} \\
(0.0480)\end{array}$ \\
\hline Observations & 4,166 & 4,166 & 4,166 & 4,166 & 4,166 & 4,166 & 4,166 & 4,166 \\
\hline controls and mills ratio & yes & Yes & yes & Yes & yes & yes & yes & yes \\
\hline Year\&Industry fixed effects & yes & Yes & yes & Yes & yes & yes & yes & yes \\
\hline Adj. $R^{2}$ & 0.0655 & 0.0799 & 0.0625 & 0.0766 & 0.0691 & 0.0808 & 0.0660 & 0.0774 \\
\hline
\end{tabular}


Table 6

\section{PSM-DID treatment effect estimation}

This table presents the estimation results for the PSM-DID treatment effects on firm performance and investment. All variables are defined in Table 1.***,**, * denote significance at $1 \%, 5 \%$, and $10 \%$ level, respectively. $\Delta a d j \_r o a$ indicates the change in ROA. Investment indicates cash outflow from purchase of tangible and intangible assets.

\begin{tabular}{|c|c|c|c|c|c|c|c|c|}
\hline & & & \multirow{2}{*}{\multicolumn{2}{|c|}{ ATET }} & \\
\hline & & & & & & s.e. & z-value & p-value \\
\hline \multirow[t]{12}{*}{$\Delta a d j \_r o a$} & \multirow[t]{6}{*}{ dis_invest } & \multirow[t]{3}{*}{ model (1) } & 1year & 0.0001 & & 0.0006 & 0.27 & 0.79 \\
\hline & & & 2year & 0.0009 & $*$ & 0.0005 & 1.72 & 0.09 \\
\hline & & & 3year & 0.0003 & & 0.0006 & 0.50 & 0.62 \\
\hline & & \multirow[t]{3}{*}{ model (2) } & 1year & 0.0002 & & 0.0005 & 0.41 & 0.68 \\
\hline & & & 2year & 0.0004 & & 0.0005 & 0.81 & 0.42 \\
\hline & & & 3year & 0.0002 & & 0.0006 & 0.31 & 0.76 \\
\hline & \multirow[t]{6}{*}{ asset_sales } & \multirow[t]{3}{*}{ model (3) } & 1year & 0.0016 & $* * *$ & 0.0005 & 3.03 & 0.00 \\
\hline & & & 2year & 0.0009 & & 0.0006 & 1.58 & 0.11 \\
\hline & & & 3year & 0.0002 & & 0.0006 & 0.35 & 0.73 \\
\hline & & \multirow[t]{3}{*}{ model (4) } & 1year & 0.0015 & $* * *$ & 0.0005 & 2.93 & 0.00 \\
\hline & & & 2year & 0.0011 & $* *$ & 0.0005 & 2.10 & 0.04 \\
\hline & & & 3year & 0.0001 & & 0.0006 & 0.15 & 0.88 \\
\hline \multirow[t]{12}{*}{ investment } & \multirow[t]{6}{*}{ dis_invest } & \multirow[t]{3}{*}{ model (1) } & 1year & 0.0156 & $* * *$ & 0.0033 & 4.75 & 0.00 \\
\hline & & & 2year & 0.0143 & $* * *$ & 0.0033 & 4.36 & 0.00 \\
\hline & & & 3year & 0.0621 & & 0.0745 & 0.83 & 0.40 \\
\hline & & \multirow[t]{3}{*}{ model (2) } & 1year & 0.0136 & $* * *$ & 0.0028 & 4.79 & 0.00 \\
\hline & & & 2year & 0.0138 & $* * *$ & 0.0037 & 3.67 & 0.00 \\
\hline & & & 3year & 0.0645 & & 0.0527 & 1.23 & 0.22 \\
\hline & \multirow[t]{6}{*}{ asset_sales } & \multirow[t]{3}{*}{ model (3) } & 1year & 0.0114 & $* * *$ & 0.0034 & 3.39 & 0.00 \\
\hline & & & 2year & 0.0136 & $* * *$ & 0.0047 & 2.91 & 0.00 \\
\hline & & & 3year & 0.1119 & & 0.0913 & 1.23 & 0.22 \\
\hline & & \multirow[t]{3}{*}{ model (4) } & 1year & 0.0144 & $* * *$ & 0.0032 & 4.48 & 0.00 \\
\hline & & & 2year & 0.0109 & $* * *$ & 0.0034 & 3.18 & 0.00 \\
\hline & & & 3year & 0.0623 & & 0.0528 & 1.18 & 0.24 \\
\hline
\end{tabular}

